\title{
HEAT STRESS-INDUCED ALTERATIONS IN ANTIOXIDATIVE ENZYMES OF SOME PLANTS OF CUCURBITACEA FAMILY
}

\author{
Cigdem Aydogan ${ }^{1, *}$, Sergul Ergin ${ }^{1}$, Ece Turhan ${ }^{1}$ \\ ${ }^{1}$ Eskisehir Osmangazi University, Faculty of Agriculture, Department of Agricultural Biotechnology, 26160, Eskişehir, \\ Turkey
}

Current Trends in

Natural Sciences

\begin{abstract}
The effects of high temperatures on melon cvs. Miranda and Poli, watermelon cv. Crimson Tide and zucchini cv. Asma leaves. The leaves obtained from plants were subjected to $35,40,45,50,55$ and $60^{\circ} \mathrm{C}$ temperatures with gradual increments every 30-minutes. Samples, obtained at each treatment, were analyzed for ascorbic acid content, NADP $(H)$ oxidase, catalase, gluthatione reductase, peroxidases activities and isoperoxidase patterns. The ascorbic acid content slightly increased parallel to temperature increment in zucchini but did not change in watermelon and in both melon cultivars. Melon cv. Poli exhibited comparatively less oxidative damage than $c v$. Miranda with a lower NAD $(P) H$ oxidase activity. Heat stress induced $N A D(P) H$ activity in watermelon and zucchini comparing to control plants. Results revealed that antioxidative enzyme activities were increased generally up to $50^{\circ} \mathrm{C}$ then decreased gradually in melon cultivars. Besides cv. Poli generally had higher enzyme activities than cv. Miranda. The activity of catalaes become prominent in watermelon while the activity of ascorbate peroxidase become prominent in zucchini. Acidic isoperoxidase bands with different relative mobility values were found in all species. Besides, basic isoperoxidase band could not be determined in both melon cultivars and watermelon while a basic isoperoxidase band was found in zucchini.
\end{abstract}

Keywords: Ascorbic acid, cucurbits, enzymatic antioxidants, high temperature stress, isoenzyme

\section{INTRODUCTION}

Plants face various stress factors throughout their lifespans. Heat stress is one of the major threat to plant survival especially in the arid regions (Jin et al., 2011). Besides, considerably affecting plant growth and yield (Ahmad and Prasad 2012), high temperature is one of the major concern for crop production due to global warming ( $\mathrm{Hu}$ et al., 2020). Plant responses to abiotic stresses are multigenic therefore it is difficult to identify, control and manipulate (Ben-Ari and Lavi, 2012). Hence, understanding the complexities of heat tolerance mechanisms is a key to manipulate tolerance in plants (Milner, 2020). The plant responses to heat stress vary depending on the plant and even the tissue or organ within the same plant affected (Peer et al., 2020). The devastating effects of heat stress on plant metabolism includes, disrupting cellular homeostasis and uncoupling major physiological and biochemical processes.

A direct consequence of stress-induced cellular changes is the production of excessive reactive oxygen species (ROS), which are produced in plants in such a way that they are confined to a small area and are also produced in a non-specific pattern in biological responses (Awasthi et al., 2015). The ROS (superoxide; $\mathrm{O}_{2}^{-}$, hydroxyl radicals; $\bullet \mathrm{OH}$, and non-radicals such as hydrogen peroxide; 
$\mathrm{H}_{2} \mathrm{O}_{2}$ and singlet oxygen ${ }^{1} \mathrm{O}_{2}$ ) are highly reactive and toxic and damage proteins, lipids, carbohydrates, resulting in oxidative stress (Rehman et al., 2020). The rate of ROS production and scavenging is critical in determining the oxidative load of plant tissue. Hydrogen peroxide accumulation itself can trigger higher ROS production by disrupting photosynthesis and activities of nicotinamide adenine dinucleotide phosphate $[\mathrm{NAD}(\mathrm{P}) \mathrm{H}]$-dependent oxidase (Ara et al., 2013; $\mathrm{Du}$ et al., 2013). Catalysing the production of $\mathrm{O}_{2}^{-} \mathrm{NAD}(\mathrm{P}) \mathrm{H}$ oxidase (EC 1.6.3.1) takes place in diverse essential processes in plants (Qu et al., 2017).

Plants can cope with ROS by their antioxidant defence system which consists of non-enzymatic and enzymatic antioxidants (Gill and Tuteja, 2010). Ascorbic acid (AsA), reduced glutathione, (GSH) and proline are some non-enzymatic antioxidants. Besides, superoxide dismutase (SOD, EC 1.15.1.1), catalase (CAT, EC 1.11.1.6), glutathione reductase (GR, EC 1.6.4.2), ascorbate peroxidase (APOX, EC 1.11.1.11) are some enzymatic antioxidants (Hasanuzzaman et al., 2020). Ascorbic acid is synthesized in mitochondria and transported to almost all parts of the plant (Foyer, 2015). Simultaneous effect of AA, $\alpha$-tocopherol and GSH, results in detoxification of ROS, which limits oxidative stress in plants (Hameed et al., 2012). Ascorbic acid has different effects under abiotic stress conditions and used by APOX as a substrate. (Tripathy and Oelmüller, 2012). The first defence of plants against ROS is that the SOD enzyme converts $\mathrm{O}_{2}{ }^{-}$radicals to $\mathrm{H}_{2} \mathrm{O}_{2}$. Then $\mathrm{H}_{2} \mathrm{O}_{2}$ is reduced to water and molecular oxygen by CAT, APOX and peroxides, thus preventing further damage to the cell membrane (Hasanuzzaman et al., 2019). Peroxidases (POX, EC 1.11.1.7) is a family of isozymes found in all plants, which uses $\mathrm{H}_{2} \mathrm{O}_{2}$ or $\mathrm{O}_{2}$ for the oxidation of various molecules, has a hem-containing monomeric glycoprotein structure, and is classified as acidic, neutral or basic according to their isoelectric points (Rajput et al., 2021). They are involved in many physiological events such as lignin biosynthesis, response to biotic and abiotic stress (Gaspar et al., 1982; Vicuna, 2005).

The antioxidant system is genotype dependent and is tissue specific. Tolerant cultivars have higher levels of antioxidant enzymes under stress conditions (Chaitanya et al., 2002). In addition, leaf is prone to higher ROS production since it is the plant organ where photosynthetic and transpiration processes take place (Jin et al., 2011). For this reason, leaves undergo significant physiological and biochemical alterations that serve as good biomarkers showing the tolerance of plants during stress exposure (Ara et al., 2015). Characterization of the antioxidative defence system in plant cultivars and organs, as increased production of ROS in response to stress is a common phenomenon, can be used as a diagnostic indicator in breeding programs regarding stress tolerance (Naji and Devaraj, 2011; Queirós et al., 2011; Ara et al., 2015).

Being a rich sources of nutrients, vegetables are consumed as daily staple food in all parts of the World and are very sensitive to abiotic stresses (Ara et al., 2013). Considering their growing periods, one of the most important environmental factors affecting the growth and development of cucurbits is high temperature. This study was conducted to investigate the effects of high temperatures on melon cvs. Miranda and Poli, watermelon cv. Crimson Tide and zucchini cv. Asma leaves.

\section{MATERIALS AND METHODS}

The samples were collected from the plants grown in a field under favourable conditions in Eskisehir, Turkey (longitude: 39 $45^{\prime} 38^{\prime \prime} \mathrm{N}$, latitude: 30²8'47"E). Leaves were collected from cucurbit plants (Cucumis melo L. cvs. Miranda and Poli, Citrillus lanatus L. cv. Crimson Tide and Cucurbita pepo L. cv. Asma in vegetative stage. The average temperatures were measured as 22-24 
${ }^{\circ} \mathrm{C}$ when the plants were grown. The controlled heat tests were applied to the leaf samples based on the method of Arora et al. (1998). For this purpose, leaves obtained from plants were collected into pyrex tubes with caps closed and placed into water bath. After a 30 -minute habituation at $30^{\circ} \mathrm{C}$, the water temperature was escalated to $35,40,45,50,55$ and $60{ }^{\circ} \mathrm{C}$ temperatures with gradual increments every half an hour. Samples, obtained at each treatment temperature, were immediately fixed in liquid nitrogen and stored at $-80{ }^{\circ} \mathrm{C}$ until further analysis.

$\mathrm{NAD}(\mathrm{P}) \mathrm{H}$ oxidase was assayed according to Cakmak and Marschner (1988); leaf samples (0.5 g) were homogenized in $5 \mathrm{~mL}$ of extraction buffer by using chilled mortar and pestle. The extraction

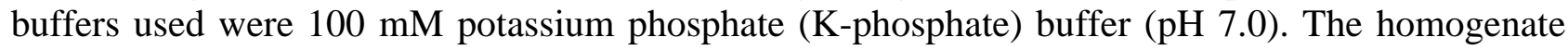
was centrifuged at $15000 \mathrm{~g}$ for $20 \mathrm{~min}$ at $4{ }^{\circ} \mathrm{C}$. The activity of enzyme was estimated by the oxidation of NAD $(\mathrm{P}) \mathrm{H}$ or NADH using a spectrophotometer (Perkin Elmer Lambda 25 UV/VIS, Santa Clara, CA, USA) at $340 \mathrm{~nm}$.

Ascorbic acid concentrations were determined according to Schoner and Krause (1990). Briefly, 0.5 $\mathrm{g}$ fresh weight of leaf samples were homogenised in $5 \mathrm{ml}$ ice-cold $4 \%(\mathrm{v} / \mathrm{v})$ metaphosphoric acid, and centrifuged at $4000 \mathrm{~g}$ for $10 \mathrm{~min}$. One $\mathrm{ml}$ of the supernatant was sampled, mixed with $1 \mathrm{~mL} 50$ $\mathrm{mM} \mathrm{Na}$ citrate buffer ( $\mathrm{pH}$ 2.6) and $1 \mathrm{~mL} 10 \mathrm{mM}$ dichlorophenolindophenol (DCPIP) and incubated at $25^{\circ} \mathrm{C}$ for $1 \mathrm{~min}$. The optical intensity of the solution was determined at $524 \mathrm{~nm}$ and compared with those of standard AsA solutions.

For extraction of antioxidative enzymes, leaf samples $(0.5 \mathrm{~g})$ were homogenized in $5 \mathrm{~mL}$ of extraction buffer by using chilled mortar and pestle. The extraction buffers used were; $100 \mathrm{mM} \mathrm{K}$ phosphate buffer (pH7.0) for CAT, $50 \mathrm{mM} \mathrm{K-phosphate} \mathrm{(pH} \mathrm{7.6)} \mathrm{for} \mathrm{GR,} \mathrm{and} 50 \mathrm{mM}$ K-phosphate buffer ( $\mathrm{pH} \mathrm{7.8)} \mathrm{for} \mathrm{APOX} \mathrm{activities.} \mathrm{The} \mathrm{activity} \mathrm{of} \mathrm{CAT} \mathrm{was} \mathrm{estimated} \mathrm{according} \mathrm{to} \mathrm{Rao} \mathrm{et} \mathrm{al.}$ (1996) by recording the decrease of absorption at $240 \mathrm{~nm}$ in as $\mathrm{H} 2 \mathrm{O} 2(\varepsilon=39.4 \mathrm{mM} / \mathrm{cm})$ was consumed. The GR activity was measured spectrophotometrically at $340 \mathrm{~nm}(\varepsilon=6.22 \mathrm{mM} / \mathrm{cm})$ by the method of Cakmak and Marschner (1992), corresponding the oxidation of $\beta$-nicotinamide adenine dinucleotide phosphate (NADPH) and the method of Nakano and Asada (1980) was employed for the assay of APOX by monitoring the decrease in oxidized AsA $(\varepsilon=2.8 \mathrm{mM} / \mathrm{cm})$ at $290 \mathrm{~nm}$.

The activities of soluble peroxidase (S-POX) and cell wall bound-peroxidase (CWB-POX) in the leaf tissues were determined spectrophotometrically according to Andrews et al. (2000). Shortly, $1.0 \mathrm{~g}$ of leaf tissue was extracted using a mortar and pestle and $5 \mathrm{~mL} 100 \mathrm{mM} \mathrm{K}$-phosphate buffer $\left(\mathrm{pH}\right.$ 7.0). The extract was centrifuged at $15000 \mathrm{~g}$ for $20 \mathrm{~min}$ at $4^{\circ} \mathrm{C}$. The supernatant was used to assay for S-POX activity. The CWB pellet was washed four-times with the same buffer, and incubated on ice in $5 \mathrm{~mL} 1 \mathrm{M} \mathrm{NaCl}$ for $5 \mathrm{~h}$. The CWB suspension was then dialysed against distilled water at $4^{\circ} \mathrm{C}$ for $48 \mathrm{~h}$ and centrifuged at $10000 \mathrm{~g}$ for $30 \mathrm{~min}$ at $4^{\circ} \mathrm{C}$. The supernatant was used for enzyme assays. The POX activity was also measured according to Andrews et al. (2000) and was expressed by reference to a standard curve using horseradish peroxidase (Sigma-Aldrich). The soluble protein content of the crude enzyme extracts was determined by the Bradford assay method using bovine serum albumin (BSA, Sigma) as standard (Bradford, 1976).

A discontinuous polyacrylamide gel electrophoresis (PAGE) under nondenaturing, nonreducing conditions was performed for the detection of isoperoxidases. The method of Gulen and Eris (2003) was used for the POX extraction from leaf samples. In brief, $0.1 \mathrm{~g}$ of ground leaf samples were homogenized with $0.6 \mathrm{~mL} 0.1 \mathrm{M} \mathrm{K}$-phosphate buffer $(\mathrm{pH} 7.5)$. The homogenate was centrifuged at $21000 \mathrm{~g}$ for $20 \mathrm{~min}$. at $4{ }^{\circ} \mathrm{C}$ and the supernatant was used for POX electrophoresis. Samples were subjected to PAGE using a Mini-PROTEAN tetra cell electrophoresis system (Bio-Rad, Hercules, 
CA) as described by Davis (1964) and Reisfeld et al. (1962) for acidic and basic POX, respectively. The method of Wendel and Weeden (1989) was used for staining of the gels. Therelative mobility (Rf) value of the bands on the gel was calculated by using $\mathrm{Rf}=1.0$, as the distance to the finishing point of the running and $\mathrm{Rf}=0.0$, as the starting point of the running (Manganaris and Alston, 1992). The experiment was set up as a randomized block design. All of the assays were repeated three times. The mean values of the data were evaluated using Duncan test at $\mathrm{p}<0.05$ using the SPSS software (version 20., Chicago, IL, USA)..

\section{RESULTS AND DISCUSSIONS}

We found that exposure to high temperatures caused differential responses of NAD(P)H oxidase enzyme activity in cucurbit plants (Figure 1). Heat stress caused a decreased the activity of $\mathrm{NAD}(\mathrm{P}) \mathrm{H}$ oxidase enzyme in both melon cultivars comparing to control treatment. In general, melon cv. Poli exhibited comparatively less oxidative damage than cv. Miranda with a lower $\mathrm{NAD}(\mathrm{P}) \mathrm{H}$ oxidase enzyme activity (Figure $1 \mathrm{~A}, \mathrm{p}<0.05)$. Difference with regard to $\mathrm{NAD}(\mathrm{P}) \mathrm{H}$ oxidase between cultivars was more prominent at $50{ }^{\circ} \mathrm{C}$ treatment with $17.74 \mathrm{nmol} / \mathrm{mg}$ protein $/ \mathrm{min}$ and $8.13 \mathrm{nmol} / \mathrm{mg}$ protein/min in $\mathrm{cv}$. Miranda and cv. Poli, respectively. The NAD(P)H oxidase enzyme activity of watermelon increased comparing to control plants especially after $50{ }^{\circ} \mathrm{C}$ significantly (Figure $1 \mathrm{~B}, \mathrm{p}<0.05$ ). The greatest $\mathrm{NAD}(\mathrm{P}) \mathrm{H}$ oxidase enzyme activity at $50{ }^{\circ} \mathrm{C}, 55^{\circ} \mathrm{C}$, and $60{ }^{\circ} \mathrm{C}$ treatment $(7.22 \mathrm{nmol} / \mathrm{mg}$ protein/min, $7.02 \mathrm{nmol} / \mathrm{mg}$ protein $/ \mathrm{min}$ and $6.78 \mathrm{nmol} / \mathrm{mg}$ protein/min, respectively) was observed in watermelon cv Crimson Tide. Statistical analysis revealed a significant effect of high temperature treatments on $\mathrm{NAD}(\mathrm{P}) \mathrm{H}$ oxidase enzyme activity of watermelon. The increment of $\mathrm{NAD}(\mathrm{P}) \mathrm{H}$ oxidase enzyme activity with elevating temperature was remarkable at $60{ }^{\circ} \mathrm{C}$ in zucchini plants with $9.75 \mathrm{nmol} / \mathrm{mg}$ protein/min enzyme activity (Figure $1 \mathrm{C}, \mathrm{p}<0.05)$.

\section{NAD(P)H oxidase activity (nmol/mg prot./min)}
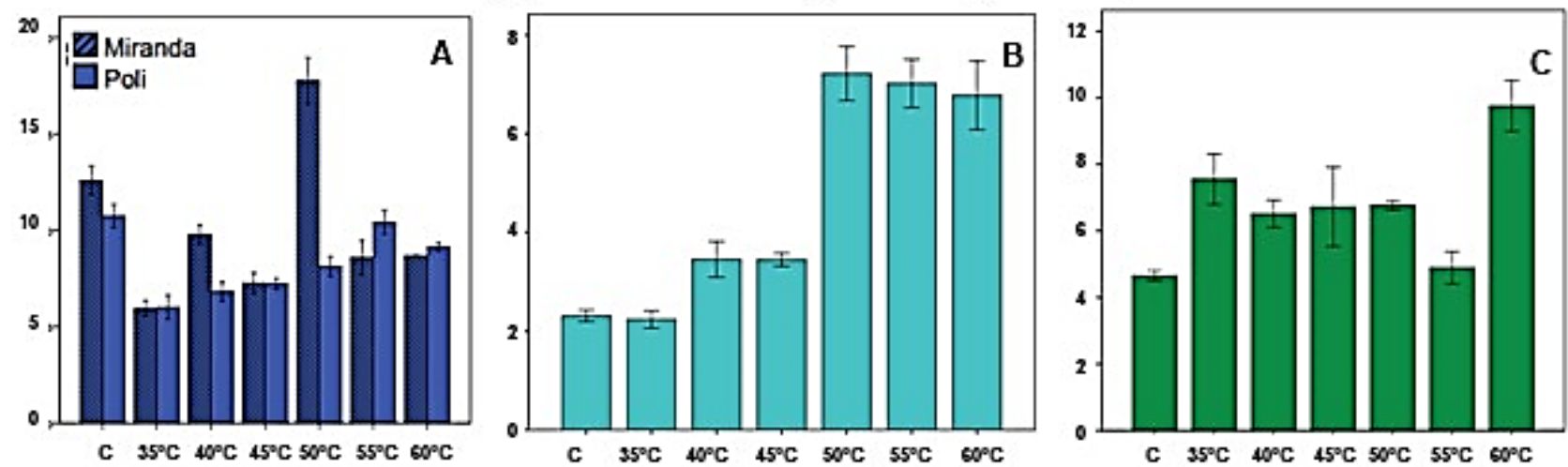

Figure 1. Effects of high temperature stress on $N A D(P) H$ oxidase activity of $(A)$ melon, (B) watermelon, and $(C)$ zucchini plants. Values are means from three replications and vertical bars indicate \pm standard error (S.E.)

There are many studies showing that $\mathrm{NAD}(\mathrm{P}) \mathrm{H}$ oxidases, localized in the plasma membrane are major producers of ROS in plants under both normal and stress conditions (Foreman et al., 2003; Sagi and Fluhr, 2006; Wang et al., 2016). Heat stress decreased the activity of NAD(P)H oxidase in Gossypium hirsutum plants (Snider et al., 2009). In the present study, cucurbit plants respond 
differentially by the means of NAD $(\mathrm{P}) \mathrm{H}$ oxidase activity. Since ROS are both substrate and product in $\mathrm{NAD}(\mathrm{P}) \mathrm{H}$ oxidase enzyme reactions, the change in $\mathrm{NAD}(\mathrm{P}) \mathrm{H}$ oxidase activity thought to be related with the ROS scavenging capacity, thus tolerance of plants to heat stress.

The changes in AsA content of the leaf tissues are shown in Figure 2. According to average values, the AsA content did not change in in both melon cultivars (Figure 2A) and watermelon (Figure 2B). Statistical analysis revealed no significant effect of temperature, and cultivar on AsA content of melon cultivars. Although the interaction of treatment*cultivar was statistically significant $(p<0.05)$. The AsA content slightly increased parallel to temperature increment $(p<0.005)$ in zucchini (Figure $2 \mathrm{C}$ ) and was the highest at $55^{\circ} \mathrm{C}(0.66 \mathrm{mg} / \mathrm{gFW})$.

The AsA scavenge the most dangerous ROS forms, namely $\bullet \mathrm{OH}, \mathrm{O}_{2}{ }^{-}$and $\mathrm{H}_{2} \mathrm{O}_{2}$, through the reaction catalysed by APOX while GSH involves in the maintenance of reduced state of the cellular pool of AsA via the Halliwell-Asada pathway (Asthir, 2015). The absence of change in AsA content of melon and watermelon cultivars in response to heat treatments indicated that AsA has no effect on heat-tolerance of this species. Besides the increment of AsA content in zucchini plants may related to ROS-scavenging capacity. In lily plants AsA concentration was largely unaffected compared to the control at $37^{\circ} \mathrm{C}$ and $42{ }^{\circ} \mathrm{C}$, except for a significant increase after $2 \mathrm{~h}$ of $42{ }^{\circ} \mathrm{C}$. The AsA concentration showed slight alternation within first six hours and then significantly decreased compared to the control at $47^{\circ} \mathrm{C}$ (Yin et al., 2008). The AsA content of strawberry plants did not change depending on heat stress (gradual temperature increment or heat shock) and were not effective in gaining tolerance (Ergin et al., 2016).

\section{AsA content (mg/gFW)}
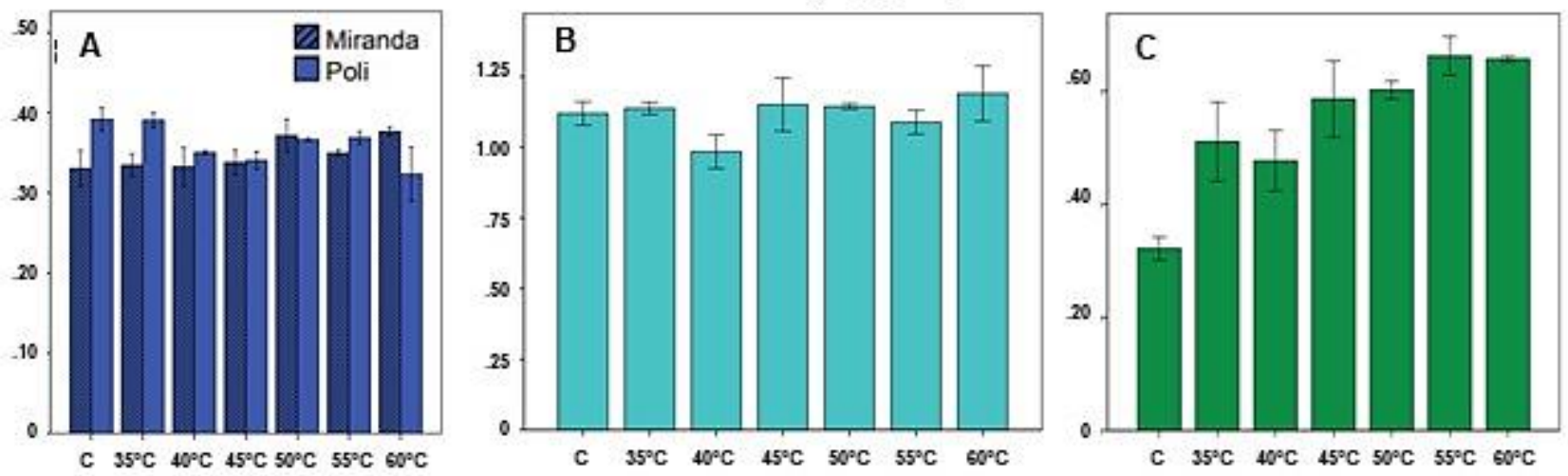

Figure 2. Effects of high temperature stress on AsA content of (A) melon, (B) watermelon, and (C) zucchini plants. Values are means from three replications and vertical bars indicate \pm S.E.

A gradual increase of temperature resulted in an activity peak at $50{ }^{\circ} \mathrm{C}, 45^{\circ} \mathrm{C}, 40{ }^{\circ} \mathrm{C}$ respectively for CAT, GR, and APOX enzymes that rapidly declined to nearly control levels in both cultivars (Table 1). The highest CAT enzyme activities were $48.55 \mathrm{nmol} / \mathrm{mg}$ protein $/ \mathrm{min}$ and $48.13 \mathrm{nmol} / \mathrm{mg}$ protein/min in cv. Miranda and cv. Poli, respectively $(\mathrm{p}<0.005)$. Statistical analysis revealed a significant effect of heat treatment, cultivar, and the interaction of heat treatment and cultivar on CAT activity. The peak values of GR enzyme activity were 5.56 units $/ \mathrm{mg}$ protein $/ \mathrm{min}$ and 5.54 units/mg protein/min in cv. Miranda and cv. Poli, respectively $(\mathrm{p}<0.005)$. Statistical analysis revealed a significant effect of heat treatment, cultivar, and the interaction of heat treatments and cultivar on GR activity. The highest APOX enzyme activities were $0.44 \mu \mathrm{mol} / \mathrm{mg}$ protein $/ \mathrm{min}$ and 
$0.54 \mu \mathrm{mol} / \mathrm{mg}$ protein $/ \mathrm{min}$ in cv. Miranda and cv. Poli, respectively $(\mathrm{p}<0.005)$. Statistical analysis revealed a significant effect of heat treatment, cultivar, and the interaction of heat treatment and cultivar on APOX activity.

Heat stress caused an activity peak at $40{ }^{\circ} \mathrm{C}$ and $35{ }^{\circ} \mathrm{C}$ for CAT $(14.37 \mathrm{nmol} / \mathrm{mg}$ protein/min $)$ and GR (40.60 units/mg protein/min) enzyme activities in watermelon, respectively then rapidly declined (Table 1). Although showing fluctuations in the APOX activity, a sharp decrease, from $0.15 \mu \mathrm{mol} / \mathrm{mg}$ protein/min to $0.01 \mu \mathrm{mol} / \mathrm{mg}$ protein $/ \mathrm{min}$, was present at $35^{\circ} \mathrm{C}$ and never reached to control levels. Statistically significant differences were found between heat treatments on CAT, GR and APOX activities of watermelon plants $(\mathrm{p}<0.05)$.

Table 1. The CAT (nmol/mg protein/min.), GR (units/mg protein/min), APOX (umol/mg protein/min.), S-POX (units/mg protein), and CWB-POX (units/mg protein) activities of cucurbit plants at different heat treatments. Values are mean $\pm S E(n=3)$. Different letters indicate significant difference among various temperature treatments of each species/cultivars $(p<0.05)$

\begin{tabular}{|c|c|c|c|c|c|c|}
\hline \multirow{2}{*}{$\begin{array}{l}\text { Species/ } \\
\text { Cultivar }\end{array}$} & \multirow{2}{*}{ Treatment } & \multicolumn{5}{|c|}{ Enzyme } \\
\hline & & CAT & GR & APOX & S-POX & CWB-POX \\
\hline \multirow{7}{*}{$\begin{array}{l}\text { Melon/ } \\
\text { Miranda }\end{array}$} & Control & $33.07 \pm 2.29 c$ & $3.14 \pm 0.27 \mathrm{~d}$ & $0.34 \pm 0.03 b c$ & $715.18 \pm 23.68 \mathrm{ab}$ & $866.29 \pm 69.16 \mathrm{a}$ \\
\hline & $35^{\circ} \mathrm{C}$ & $35.87 \pm 2.29 b c$ & $3.51 \pm 0.22 \mathrm{~cd}$ & $0.38 \pm 0.03 \mathrm{ab}$ & $514.55 \pm 23.68 c$ & $735.40 \pm 56.47 \mathrm{ab}$ \\
\hline & $40^{\circ} \mathrm{C}$ & $38.97 \pm 2.29 b c$ & $4.49 \pm 0.22 b$ & $0.44 \pm 0.03 \mathrm{a}$ & $468.49 \pm 29.00 c$ & $627.10 \pm 56.47 \mathrm{ab}$ \\
\hline & $45^{\circ} \mathrm{C}$ & $41.93 \pm 2.81 b c$ & $5.56 \pm 0.27 \mathrm{a}$ & $0.37 \pm 0.03 \mathrm{ab}$ & $563.70 \pm 23.68 c$ & $649.94 \pm 56.47 \mathrm{ab}$ \\
\hline & $50^{\circ} \mathrm{C}$ & $48.55 \pm 2.29 \mathrm{a}$ & $3.95 \pm 0.27 b c$ & $0.44 \pm 0.03 \mathrm{a}$ & $655.84 \pm 29.00 b$ & $841.37 \pm 69.16 \mathrm{a}$ \\
\hline & $55^{\circ} \mathrm{C}$ & $36.07 \pm 2.81 b c$ & $2.44 \pm 0.27 \mathrm{e}$ & $0.20 \pm 0.03 d$ & $677.00 \pm 23.68 \mathrm{ab}$ & $565.93 \pm 69.16 b c$ \\
\hline & $60^{\circ} \mathrm{C}$ & $34.50 \pm 2.81 \mathrm{c}$ & $3.48 \pm 0.27 \mathrm{~cd}$ & $0.27 \pm 0.03 \mathrm{~cd}$ & $764.29 \pm 29.00 \mathrm{a}$ & $350.47 \pm 69.16 c$ \\
\hline \multirow[t]{7}{*}{ Melon/ Poli } & Control & $23.41 \pm 2.29 \mathrm{~b}$ & $3.27 \pm 0.27 d$ & $0.43 \pm 0.03 b c$ & $568.99 \pm 29.00 \mathrm{c}$ & $459.79 \pm 56.47 \mathrm{ab}$ \\
\hline & $35^{\circ} \mathrm{C}$ & $27.47 \pm 2.29 b$ & $4.21 \pm 0.22 b c$ & $0.48 \pm 0.03 \mathrm{ab}$ & $668.16 \pm 29.00 \mathrm{~b}$ & $497.92 \pm 69.16 \mathrm{a}$ \\
\hline & $40^{\circ} \mathrm{C}$ & $39.43 \pm 2.29 \mathrm{a}$ & $5.23 \pm 0.27 \mathrm{a}$ & $0.54 \pm 0.03 \mathrm{a}$ & $599.03 \pm 29.00 \mathrm{bc}$ & $463.47 \pm 69.16 \mathrm{ab}$ \\
\hline & $45^{\circ} \mathrm{C}$ & $44.10 \pm 2.29 \mathrm{a}$ & $5.01 \pm 0.22 \mathrm{ab}$ & $0.47 \pm 0.03 \mathrm{ab}$ & $487.51 \pm 29.00 \mathrm{~d}$ & $561.60 \pm 69.16 \mathrm{a}$ \\
\hline & $50^{\circ} \mathrm{C}$ & $48.13 \pm 2.29 \mathrm{a}$ & $5.54 \pm 0.27 \mathrm{a}$ & $0.38 \pm 0.03 c$ & $770.81 \pm 29.00 \mathrm{a}$ & $488.76 \pm 69.16 \mathrm{a}$ \\
\hline & $55^{\circ} \mathrm{C}$ & $40.99 \pm 2.29 a$ & $4.88 \pm 0.27 \mathrm{ab}$ & $0.37 \pm 0.03 c$ & $534.46 \pm 23.68 \mathrm{~cd}$ & $420.26 \pm 69.16 \mathrm{ab}$ \\
\hline & $60^{\circ} \mathrm{C}$ & $24.62 \pm 2.29 b$ & $4.03 \pm 0.27 \mathrm{~cd}$ & $0.29 \pm 0.03 d$ & $303.66 \pm 23.68 \mathrm{e}$ & $330.16 \pm 56.47 b$ \\
\hline \multirow{7}{*}{$\begin{array}{l}\text { Watermelon/ } \\
\text { Crimson Tide }\end{array}$} & Control & $5.71 \pm 1.81 \mathrm{a}$ & $17.68 \pm 0.83 d$ & $0.15 \pm 0.01 \mathrm{c}$ & $4051.31 \pm 416.67 \mathrm{a}$ & $0.13 \pm 0.19 \mathrm{a}$ \\
\hline & $35^{\circ} \mathrm{C}$ & $6.11 \pm 1.47 \mathrm{a}$ & $40.60 \pm 1.02 \mathrm{e}$ & $0.01 \pm 0.01 \mathrm{a}$ & $3735.65 \pm 416.67 \mathrm{a}$ & $0.31 \pm 0.24 a$ \\
\hline & $40^{\circ} \mathrm{C}$ & $14.37 \pm 1.81 \mathrm{~b}$ & $2.61 \pm 1.02 \mathrm{a}$ & $0.07 \pm 0.01 b$ & $3071.73 \pm 416.67 \mathrm{a}$ & $0.24 \pm 0.19 a$ \\
\hline & $45^{\circ} \mathrm{C}$ & $13.96 \pm 1.47 \mathrm{~b}$ & $5.07 \pm 0.83 \mathrm{ab}$ & $0.02 \pm 0.01 \mathrm{a}$ & $3729.31 \pm 416.67 \mathrm{a}$ & $0.34 \pm 0.24 \mathrm{a}$ \\
\hline & $50^{\circ} \mathrm{C}$ & $9.35 \pm 1.47 \mathrm{ab}$ & $6.38 \pm 0.83 b c$ & $0.02 \pm 0.01 \mathrm{a}$ & $2937.24 \pm 416.67 \mathrm{a}$ & $0.11 \pm 0.24 \mathrm{a}$ \\
\hline & $55^{\circ} \mathrm{C}$ & $5.79 \pm 1.47 \mathrm{a}$ & $5.43 \pm 0.83 a b c$ & $0.06 \pm 0.01 b$ & $2683.21 \pm 416.67 \mathrm{a}$ & $0.30 \pm 0.24 \mathrm{a}$ \\
\hline & $60^{\circ} \mathrm{C}$ & $13.2 \pm 1.47 \mathrm{~b}$ & $8.09 \pm 0.83 c$ & $0.03 \pm 0.01 \mathrm{a}$ & $6072.63 \pm 416.67 b$ & $2.73 \pm 0.24 b$ \\
\hline \multirow{7}{*}{$\begin{array}{l}\text { Zucchini/ } \\
\text { Asma }\end{array}$} & Control & $72.04 \pm 8.66 \mathrm{~b}$ & $13.78 \pm a b c$ & $0.05 \pm 0.02 \mathrm{a}$ & $3186.39 \pm 170.62 c$ & $0.08 \pm 0.01 \mathrm{bcd}$ \\
\hline & $35^{\circ} \mathrm{C}$ & $127.23 \pm 8.66 \mathrm{c}$ & $18.80 \pm \mathrm{c}$ & $0.03 \pm 0.02 \mathrm{a}$ & $1473.54 \pm 170.62 b$ & $0.09 \pm 0.01 \mathrm{bcd}$ \\
\hline & $40^{\circ} \mathrm{C}$ & $57.75 \pm 10.61 \mathrm{ab}$ & $14.42 \pm \mathrm{abc}$ & $0.08 \pm 0.02 \mathrm{a}$ & $1528.96 \pm 170.62 b$ & $0.05 \pm 0.01 \mathrm{a}$ \\
\hline & $45^{\circ} \mathrm{C}$ & $78.58 \pm 10.61 b$ & $12.41 \pm \mathrm{ab}$ & $0.31 \pm 0.02 c$ & $1290.83 \pm 170.62 \mathrm{ab}$ & $0.07 \pm 0.01 \mathrm{abc}$ \\
\hline & $50^{\circ} \mathrm{C}$ & $25.55 \pm 10.61 \mathrm{a}$ & $10.94 \pm a$ & $0.14 \pm 0.02 b$ & $1319.86 \pm 170.62 \mathrm{ab}$ & $0.11 \pm 0.01 \mathrm{~d}$ \\
\hline & $55^{\circ} \mathrm{C}$ & $87.63 \pm 10.61 b$ & $17.35 \pm b c$ & $0.14 \pm 0.02 b$ & $911.06 \pm 170.62 \mathrm{a}$ & $0.09 \pm 0.01 \mathrm{~cd}$ \\
\hline & $60^{\circ} \mathrm{C}$ & $29.27 \pm 8.66 \mathrm{a}$ & $14.24 \pm \mathrm{abc}$ & $0.16 \pm 0.02 b$ & $2815.35 \pm 170.62 \mathrm{c}$ & $0.06 \pm 0.01 \mathrm{ab}$ \\
\hline
\end{tabular}


The highest CAT enzyme activity $\left(127.38 \mathrm{nmol} / \mathrm{mg}\right.$ protein/min) of zucchini was observed at $35^{\circ} \mathrm{C}$ (Table 1). Similarly, the highest GR enzyme activity (18.80 units/mg protein/min) was found at 35 ${ }^{\circ} \mathrm{C}$. The activity of APOX enzyme increased up to $0.31 \mu \mathrm{mol} / \mathrm{mg}$ protein $/ \mathrm{min}$ at $45^{\circ} \mathrm{C}$. Statistical analysis revealed a significant effect of heat treatment on CAT, GR, and APOX activities $(\mathrm{p}<0.05)$. Increased ROS production due to abiotic stresses causes changes in their homeostasis (Polle, 2001), but also acts as signals to activate stress responses. To overcome possible oxidative stress, plants produce enzymatic (APX, CAT, GR and SOD) and non-enzymatic. antioxidants (Choudhary and Agrawal, 2014). Under heat stress conditions seedlings of watermelon cv. Crimson Sweet showed much higher CAT activity than Charleston Gray and Fairfax cultivars, although, parallel to increasing temperatures, CAT activity in the cotyledons and embryos of all watermelon cultivars increased (Dantas et al., 2015). Ara et al. (2015) found that, when plants of heat-tolerant Cucurbita moschata, thermolabile Cucurbita maxima and their moderately heat-tolerant interspecific inbred line "Maxchata" genotypes were exposed to moderate $\left(37^{\circ} \mathrm{C}\right)$ and severe $\left(42^{\circ} \mathrm{C}\right)$ heat shocks, the enzyme activities of CAT and APOX in their leaves were increased with heat stress in tolerant genotypes of Cucurbita moschata followed by "Maxchata". Different responses of leaf antioxidative enzymes were also reported in strawberry plants. While CAT and APX activities increased with high temperatures, GR activity was almost unchanged (Ergin et al., 2016). The activities of CAT, GR, and APOX enzymes in the leaf extracts of control and high temperature (40 ${ }^{\circ} \mathrm{C}$ ) were assayed and activities of all enzymes were high in all the mulberry cultivars in response to high temperature (Chaitanya et al., 2002).

The S-POX activities of both melon cultivars indicated significant differences between heat treatments (Table 1). The S-POX activity was significantly greater at $60{ }^{\circ} \mathrm{C}$ in cv. Miranda $(764.29$ units/mg protein) and at $50{ }^{\circ} \mathrm{C}$ in $\mathrm{cv}$. Poli (770.81 units/mg protein). Thus, the effects of heat treatments, cultivar, and their interactions on S-POX enzyme activity were found statistically significant $(\mathrm{p}<0.05)$. The highest CWB-POX enzyme activity was detected at control treatment with 866.29 units/mg protein in cv. Miranda and at $45{ }^{\circ} \mathrm{C}$ in cv. Poli (561.60 units $/ \mathrm{mg}$ protein). The effects of heat treatments on CWB-POX enzyme activity of cv. Miranda was statistically significant. Besides, statistical analysis revealed that, the differences between cultivars and heat treatment*cultivar interaction were statistically significant $(\mathrm{p}<0.05)$

The effects of heat treatments on S-POX and CWB-POX enzyme activities of watermelon is shown in Table 1. The highest enzyme activities were at $60{ }^{\circ} \mathrm{C}$ with 6072.63 units $/ \mathrm{mg}$ protein and 2.73 units/mg protein for S-POX and CWB-POX enzymes, respectively. In terms of S-POX and CWBPOX enzyme activities, statistically significant differences were detected between heat treatments $(\mathrm{p}<0.05)$.

The S-POX enzyme activity of zucchini was the highest at control treatment and decreased with increasing temperatures $\left(55^{\circ} \mathrm{C}\right.$ ), then increased up to 2815.35 units/mg protein at $60{ }^{\circ} \mathrm{C}$ (Table 1 ). The highest and the lowest CWB-POX enzyme activity were observed at $50{ }^{\circ} \mathrm{C}(0.11 \mathrm{units} / \mathrm{mg}$ protein) and $40{ }^{\circ} \mathrm{C}(0.05$ units/mg protein), respectively. Statistical analysis revealed a significant effect of heat treatments on both S-POX and CWB-POX activities $(\mathrm{p}<0.05)$.

Total peroxidase activity of plants is as a biomarker for stress treatments. However, results are not clear, due to the differentially regulated isoenzymes (Mika et al., 2010). Besides; the relationship of CWB-POX activity to heat stress treatments remains unclear (Turhan et al., 2014). In the present research, S-POX had effective means in determining heat tolerance of melon and zucchini plants. Previously, Turhan et al. (2014) showed that the S-POX activity was greater in the first bloom stage than in the yield stage in tomato cultivars. In contrast to S-POX activity, the CWB-POX activity 


\begin{tabular}{|c|c|}
\hline . & 37 \\
\hline $\begin{array}{l}\text { Current Trends in Natural Sciences (on-line) } \\
\text { ISSN: 2284-953X } \\
\text { ISSN-L: 2284-9521 }\end{array}$ & $\begin{array}{l}\text { Current Trends in Natural Sciences (CD-Rom) } \\
\text { ISSN: 2284-9521 } \\
\text { ISSN-L: 2284-9521 }\end{array}$ \\
\hline
\end{tabular}

was greater in the yield stage than in the first bloom stage and generally CWB-POX activity was high in the samples in response to heat stress treatments (Turhan et al., 2014). Gulen and Eris (2004) reported that total and specific POX activities were significantly increased by high temperatures in strawberry plants.

A Native PAGE was performed to observe the acidic and basic isoperoxidase profiles of leaves of cucurbit plants (Figure 3). Six acidic isoperoxidase bands were found in melon cultivar with $\mathrm{Rf}$ values of $0.14,0.42,0.45,0.48,0.52,0.55$. Two bands $(\mathrm{Rf}=0.45$ and $\mathrm{Rf}=0.48)$ were common for both melon cultivars. The intensity of the bands was decreased with heat treatments in cv. Miranda. However, in cv. Poli the bands were disappeared at $60{ }^{\circ} \mathrm{C}$ (Figure 3A). There were no basic isoperoxidase band was found in both melon cultivars.

There were four acidic isoperoxidase bands $(\mathrm{Rf}=0.06,0.20,0.76,0.88)$ in watermelon plants, though the appearance of the bands were not affected by the heat treatment (except $40{ }^{\circ} \mathrm{C}$ ) (Figure 3B). There were no basic isoperoxidase band was found in both watermelon cultivars.

The effects of heat treatments on isoperoxidase profiles of zucchini plant are shown in Figure 3C-D. Four asidic $(\mathrm{Rf}=0.31,0.36,0.40,0.59)$ and one basic $(\mathrm{Rf}=0.73)$ isoperoxidase bands were found in leaf tissues of zucchini plants. The intensity of the acidic isoperoxidase bands were decreased with heat treatments. Besides, the basic isoperoxidase band was disappeared at $60{ }^{\circ} \mathrm{C}$ (Figure 3D).

(A)
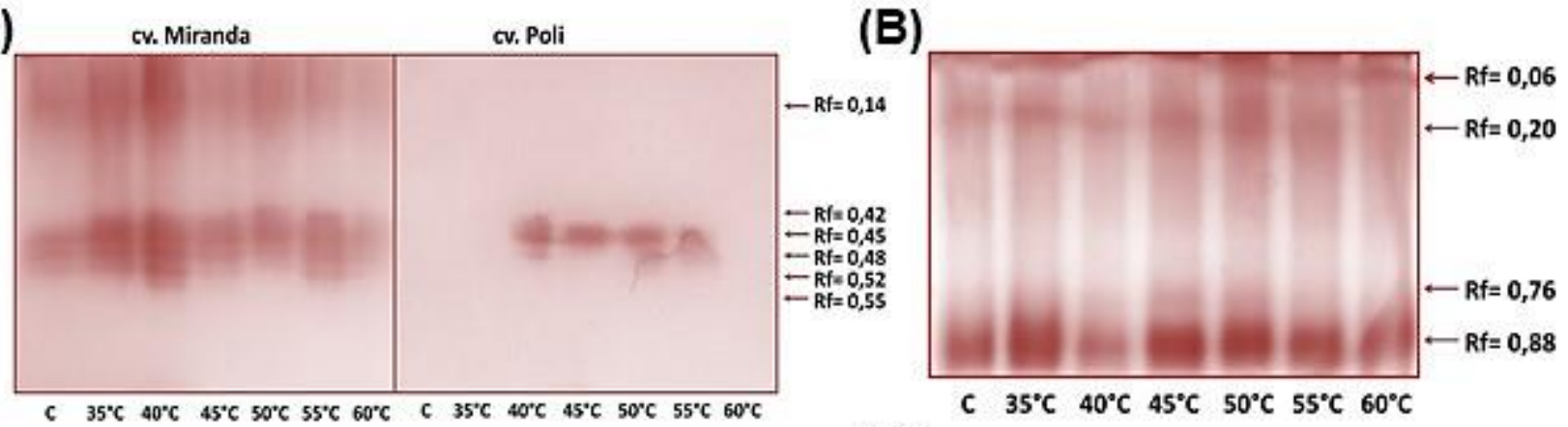

(C)

(D)
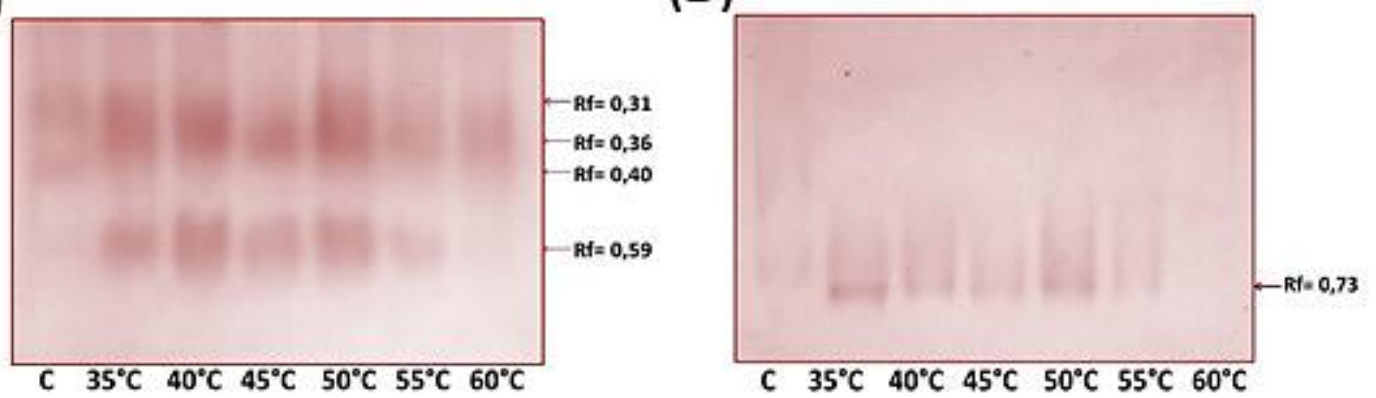

Figure 3. Effects of high temperature stress on acidic isoperoxsidase profiles of (A) melon, (B) watermelon, and (C) zucchini cucurbit plants and $(D)$ basic isoperoxidase of zucchini plants. In each lane, $20 \mu L$ of POX extract was loaded. Relative mobility of the bands is shown on the left-hand side

Peroxidases are a large group of isoenzymes with an extreme range of isoelectric points, serving a multitude of functions (Huystee, 1987). Each group is thought to have a different function in the cell. The function of basic isoperoxidases are thought to be, to provide $\mathrm{H}_{2} \mathrm{O}_{2}$ for other peroxidases 
(Walter, 1992). In previous studies, one basic isoperoxidase band $(\mathrm{Rf}=0.22)$ with different intensity due to heat treatments was detected in strawberry plants (Gulen and Eris, 2004). Similarly, Ergin et al., (2012) reported that there was no acidic isoperoxidase band was observed in strawberry plant under heat stress conditions, and a single sharp basic isoperoxidase band with $\mathrm{Rf}=0.55$ was observed in all treatments except $60^{\circ} \mathrm{C}$ treatment.

\section{CONCLUSIONS}

In conclusion, $\mathrm{NAD}(\mathrm{P}) \mathrm{H}$ oxidase and antioxidative enzyme activities were increased generally after $50{ }^{\circ} \mathrm{C}$. The results clearly show that the cv. Poli is superior with respect to its antioxidant defense systems and should be more tolerant than cv. Miranda due to higher ROS-scavenging systems. The activity of POXs (APOX and S-POX) become prominent in melon and zucchini while the activity of CAT become prominent in watermelon. Acidic isoperoxidase bands with different relative mobility values were found in all species. Besides, basic isoperoxidase band could not be determined in both melon cultivars and watermelon while a basic isoperoxidase band was found in zucchini. The cucurbit species/cultivars showed different responses to the stress imposed, suggesting different adjustment and tolerance mechanism. Additional researches must be performed regarding other antioxidant responses to each cultivar studied in this work, as well as other pathways involved in stress tolerance. Besides, the results obtained in this research forms a basis for further studies at the molecular level.

\section{REFERENCES}

Ahmad, P., Prasad, M.N.V. (2012). Environmental adaptations and stress tolerance of plants in the era of climate change (pp. 297-324). New York: Springer, New York.

Andrews, J., Malone, M., Thompson, D.S., Ho, L.C., Burton, K.S. (2000). Peroxidase isoenzyme patterns in the skin of maturing tomato fruits. Plant Cell Environ, 23, 415-422.

Ara, N., Nakkanong, K., L.V., W., Yang, J., Hu, Z., Zhang, M. (2013). Antioxidant enzymatic activities and gene expression associated with heat tolerance in the stems and roots of two cucurbit species ("Cucurbita maxima" and "Cucurbita moschata") and their interspecific inbred line "Maxchata". International Journal of Molecular Sciences, 14(12), 24008-24028.

Ara, N., Nakkanong, K., Yang, J., Hu, Z., Zhang, M. (2015). Dissecting the heat stress-induced alterations in the leaf ultrastructure and some antioxidant network components in interspecific (Cucurbita maximax Cucurbita moschata) inbred line of squash 'Maxchata' as to its parents possessing variable heat tolerance. Plant Growth Regulation, 76(3), 289-301.

Arora, R., Pitchay, D.S., Bearce, B.C. (1998). Water stress-induced heat tolerance in geranium leaf tissues: A possible linkage through stress proteins, Physiologica Plantarum, 103, 24-34.

Asthir, B. (2015). Protective mechanisms of heat tolerance in crop plants. Journal of Plant Interactions, 10(1), $202-210$.

Awasthi, R., Bhandari, K., Nayyar, H. (2015). Temperature stress and redox homeostasis in agricultural crops. Frontiers in Environmental Science, 3, 11.

Ben-Ari, G., Lavi, U. (2012). Marker-assisted selection in plant breeding. In A. Altman, P. M. Hasegawa, eds, Plant Biotechnology and Agriculture (pp. 163-184). West Lafayette: Academic Press, West Lafayette.

Bradford, M.M. (1976). A rapid and sensitive method for the quantitation of microgram quantities of protein utilizing the principle of protein-dye binding. Analytical Biochemistry, 72(1-2), 248-254.

Cakmak, I., H. Marschner. (1988). Zinc-dependent changes in ESR signals, NADPH oxidase and plasma membrane permeability in cotton roots. Physiol Plant, 73, 182-186.

Cakmak, I., Marschner, H.(1992). Magnesium deficiency and high-light intensity enhance activities of superoxide dismutase, ascorbate peroxidase and glutathione reductase in bean leaves. Plant Physiol. 98, 1222-1227.

Chaitanya, K., Sundar, D., Masilamani, S., Reddy, A.R. (2002). Variation in heat stress-induced antioxidant enzyme activities among three mulberry cultivars. Plant Growth Regul 36(2), 175-180 
Choudhary, K.K., Agrawal, S.B. (2014). Cultivar specificity of tropical mung bean (Vigna radiate L.) to elevated ultraviolet-B: changes in antioxidative defense system, nitrogen metabolism and accumulation of jasmonic and salicylic acids. Environmental and Experimental Botany, 99: 122-132.

Dantas, B.F., da Silva, R.D.C.B., Ribeiro, R.C., Aragão, C.A. (2015). Respiration and antioxidant enzymes activity in watermelon seeds and seedlings subjected to salt and temperature stresses. Journal of Experimental Agriculture International, 70-77.

Davis, B.J. (1964). Disc electrophoresis. Method and application to human serum proteins. Ann NY Acad Sci, 121, 404427.

Du, H., Zhou, P., Huang, B. (2013). Antioxidant enzymatic activities and gene expression associated with heat tolerance in a cool-season perennial grass species. Environ Exp Bot, 87, 159-166.

Ergin, S., Gülen, H., Kesici, M., Turhan, E., Ipek, A., Köksal, N. (2016). Effects of high temperature stress on enzymatic and nonenzymatic antioxidants and proteins in strawberry plants. Turkish Journal of Agriculture and Forestry, 40(6), 908-917.

Ergin, S., Kesici, M., Gülen, H. (2012). Changes in $\mathrm{H}_{2} \mathrm{O}_{2}$ and peroxidase activities in strawberry plants under heat stress. J. Agric. Fac. HR. U.,16(1):25-35.

Foreman J., Demidchik V., Bothwell J.H., Mylona P., Miedema H., Torres M.A., Linstead P., Costa S., Brownlee C., Jones J.D., Davis, J.M., Dolan, L. (2003). Reactive oxygen species produced by NADPH oxidase regulate plant cell growth. Nature, 422, 442-446.

Foyer, C.H. (2015). Redox homeostasis: opening up ascorbate transport. Nat Plants 1,1401.

Gaspar, T., Penel, C.L., Thorpe, T., Greppin, H. (1982). Peroxidases. A survey of their bio chemical and physiological roles in higher plants. Geneve: Universite de Geneve Press, Geneve.

Gill, S.S. Tuteja, N. (2010). Reactive oxygen species and antioxidant machinery in abiotic stress tolerance in crop plants. Plant Physiol Biochem, 48, 909-930.

Gulen, H., Eris, A. (2003). Some physiological changes in strawberry (Fragaria $\times$ ananassa cv. 'Camarosa') plants under heat stress. Journal of Horticultural Science and Biotechnology, 78, 894-898.

Gulen, H., Eris, A. (2004). Effect of heat stress on peroxidase activity and total protein content in strawberry plants. Plant Science, 166(3), 739-744.

Hameed, A., Goher, M., Iqbal, N. (2012). Heat stress-induced cell death, changes in antioxidants, lipid peroxidation and protease activity in wheat leaves. J Plant Growth Regul, 31, 283-291.

Hasanuzzaman, M., Bhuyan, M.H.M., Anee, T.I., Parvin, K., Nahar, K., Mahmud, J.A., Fujita, M. (2019). Regulation of ascorbate-glutathione pathway in mitigating oxidative damage in plants under abiotic stress. Antioxidants, 8(9), 384.

Hasanuzzaman, M., Bhuyan, M. H. M., Zulfiqar, F., Raza, A., Mohsin, S. M., Mahmud, J. A., Fujita, M., Fotopoulos, V. (2020). Reactive oxygen species and antioxidant defense in plants under abiotic stress: revisiting the crucial role of a universal defense regulator. Antioxidants, 9(8), 681.

$\mathrm{Hu}$, S., Ding, Y., Zhu, C. (2020). Sensitivity and responses of chloroplasts to heat stress in plants. Frontiers in plant science, 11, 375.

Huystee, R.B.V. 1987. Some molecular aspects of plant peroxidase biosynthetic studies. Annu. Review Plant Physiol., $38,205-219$

Jin, B., Wang, L., Wang, J., Jiang, K.Z., Wang, Y., Jiang, X.X., Ni, C.Y., Wang, Y.L., Teng, N.J. (2011). The effect of experimental warming on leaf functional traits, leaf structure and leaf biochemistry in Arabidopsis thaliana. BMC Plant Biol 11(1), 35.

Manganaris, A.G., Alston, F.H. (1992). Inheritance and linkage relationships of peroxidase isozymes in apple. Theor Appl Genet. 83, 392-399.

Mika, A., Boenisch, M.J., Hopff, D., Lüthje, S. (2010). Membrane-bound guaiacol peroxidases are regulated by methyl jasmonate, salicylic acid, and pathogen elicitors. J. Exp. Bot., 61, 831-841.

Milner, K. (2020). The price of heat stress: functional and resource constraints to thermal tolerance in arid zone plants. PhD Thesis. Sydney: School of Life Sciences, University of Technology Sydney.

Naji, K., Devaraj, V. (2011). Antioxidant and other biochemical defense responses of Macrotyloma uniflorum (Lam) Verdc. (Horse gram) induced by high temperature and salt stress. Braz J Plant Physiol 23(3), 187-195.

Nakano,Y., Asada, K. (1980). Spinach chloroplasts scavenge hydrogen peroxide on illumination. Plant Cell Physiol 21, 1295-1307.

Peer, L. A., Dar, Z. A., Lone, A. A., Bhat, M. Y., Ahamad, N. (2020). High temperature triggered plant responses from whole plant to cellular level. Plant Physiology Reports, 1-16. 
Polle, A. (2001). Dissecting the superoxide dismutase-ascorbate glutathione pathway in chloroplasts by metabolic modeling. Computer simulations as a step towards flux analysis. Plant Physiol., 126, 445-462.

Qu, Y., Yan, M., Zhang, Q. (2017). Functional regulation of plant NADPH oxidase and its role in signalling. Plant Signal Behav, 12(8), e1356970.

Queirós, F., Rodrigues, J.A., Almeida, J.M., Almeida, D.P., Fidalgo, F. (2011). Differential responses of the antioxidant defence system and ultrastructure in a salt-adapted potato cell line. Plant Physiol and Biochem 49(12), 1410 1419

Rajput, V. D., Singh, R. K., Verma, K. K., Sharma, L., Quiroz-Figueroa, F. R., Meena, M., Gour, V.S., Minkina, T., Sushkova, S., Mandzhieva, S. (2021). Recent Developments in Enzymatic Antioxidant Defence Mechanism in Plants with Special Reference to Abiotic Stress. Biology, 10(4), 267.

Rao, M.V., Paliyath, G., Ormrod, D.P. (1996). Ultraviolet-B- and ozone induced biochemical changes in antioxidant enzymes of Arabidopsis thaliana. Plant Physiol 110, 125-136.

Rehman, A. U., Bashir, F., Ayaydin, F., Kóta, Z., Páli, T., \& Vass, I. (2021). Proline is a quencher of singlet oxygen and superoxide both in in vitro systems and isolated thylakoids. Physiologia Plantarum, 172(1), 7-18.

Reisfeld, R.A., Lewis, U.J., Williams, D.E. (1962). Disk electrophoresis of basic proteins and peptides on polyacrylamide gels. Nature, 195, 281-283.

Sagi M., Fluhr R. (2006) Production of reactive oxygen species by plant NADPH oxidases. Plant Physiology, 141, 336340.

Schoner, S., Krause, G.H. (1990). Protective systems against active oxygen species in spinach: response to cold acclimation in excess light. Planta, 180, 383-389.

Snider, J.L., Oosterhuis, D.M., Skulman, B.W., Kawakami, E.M. (2009). Heat stress-induced limitations to reproductive success in Gossypium hirsutum. Physiologia plantarum, 137(2), 125-138.

Tripathy, B.C., Oelmüller, R. (2012). Reactive oxygen species generation and signaling in plants. Plant Signal Behav 7 , 1621-1633.

Turhan, E., Aydogan, C., Ergin, S., Ozturk, N. (2014). Variation in heat stress-induced some physiological changes and peroxidase activities among three tomato (Lycopersicon esculentum Mill.) cultivars. Turkish Journal of Agricultural and Natural Sciences, Special Issue: 2, 1492-1498.

Vicuna, D. (2005). The role of peroxidases in the development of plants and their responses to abiotic stresses. PhD thesis. Dublin: Technological University Dublin.

Walter, M.H. 1992. Regulation of lignification in defense. In Boller, T., F., Meins, eds, Plant Gene Research: Genes Involved in Plant Defense (pp 327-352). Springer: Vienna.

Wang, Y. J., Wei, X. Y., Jing, X. Q., Chang, Y. L., Hu, C. H., Wang, X., Chen, K.M. (2016). The fundamental role of NOX family proteins in plant immunity and their regulation. International journal of molecular sciences, 17(6), 805.

Wendel, J.F., Weeden, N.F. (1989). Visualization and interpretation of plant isozymes. In D.E. Soltis, P.S. Soltis, eds, Isozymes in Plant Biology (pp. 5-44). Oregon: Dioscorides Press, Oregon.

Yin, H., Chen, Q., Yi, M. (2008). Effects of short-term heat stress on oxidative damage and responses of antioxidant system in Lilium longiflorum. Plant Growth Regul, 54, 45-54. 